\title{
Characterization of 'Candidatus Syngnamydia salmonis' (Chlamydiales, Simkaniaceae), a bacterium associated with epitheliocystis in Atlantic salmon (Salmo salar L.)
}

\author{
Stian Nylund • Andreas Steigen • Egil Karlsbakk • \\ Heidrun Plarre • Linda Andersen • Marius Karlsen • \\ Kuninori Watanabe · Are Nylund
}

Received: 30 October 2013 / Revised: 12 September 2014 / Accepted: 13 September 2014 / Published online: 8 October 2014

(c) The Author(s) 2014. This article is published with open access at Springerlink.com

\begin{abstract}
Two Chlamydiales have previously been found to infect Atlantic salmon (Salmo salar L.), Candidatus Piscichlamydia salmonis and Candidatus Clavichlamydia salmonicola. Both develop intracellularly in cyst-like inclusions in gill cells, generally referred to as epitheliocysts. Here, we present evidence for the association of a novel species of Chlamydiales with epitheliocystis in Atlantic salmon. Based on its partial 16S rRNA gene sequence, it is a new member of the family Simkaniaceae, and a $95.7 \%$ identity to the type species Candidatus Syngnamydia venezia suggests inclusion in the candidate genus Syngnamydia. The presence of the bacterium in epitheliocysts in gills of Atlantic salmon was demonstrated by RNA-RNA hybridization. Ultrastructurally, the novel bacterium produces pleomorphic reticulate bodies and elementary bodies (EBs) with a characteristic morphology. The EBs are short rods with a terminal disc-like cap area, a sub-apical spherical vacuole-like electron-lucent structure and a post-equatorial nucleoid. We propose the name Candidatus Syngnamydia salmonis for this new agent from epitheliocysts in seawater-reared salmon.
\end{abstract}

Keywords Epitheliocystis - Chlamydia - Simkaniaceae . Syngnamydiae $\cdot$ Atlantic salmon

Communicated by Andreas Brune.

S. Nylund $\cdot$ A. Steigen $(\bowtie) \cdot$ E. Karlsbakk $\cdot$ H. Plarre

L. Andersen $\cdot$ M. Karlsen $\cdot$ K. Watanabe $\cdot$ A. Nylund

Department of Biology, University of Bergen, P.O. Box 7803, 5020 Bergen, Norway

e-mail: andreas.steigen@bio.uib.no

E. Karlsbakk

Institute of Marine Research, P.O. Box 1870, 5817, Nordnes,

Bergen, Norway

\section{Introduction}

Hoffman coined the term epitheliocystis (Hoffman et al. 1969) for cyst-like epidermal lesions in fish caused by bacteria ultrastructurally resembling chlamydiae (as Bedsonia-like = Chlamydia-like; Bedsonia a synonym of Chlamydia). The bacteria occur intracellularly in cyst-like inclusions; usually resulting in significantly enlarged infected cells (epitheliocystis cells). Additional evidence for a chlamydial aetiology of epitheliocystis in various fish species came from further ultrastructural observations, including documentation of a two-stage replication cycle including vegetative reticulate bodies (RBs) and infectious elementary bodies (EBs; Paperna et al. 1981; Nylund et al. 1998). Genetic studies of these agents of epitheliocystis have confirmed that they usually are members of the order Chlamydiales and established that the genetic diversity among them is large (Draghi et al. 2004; Meijer et al. 2006; Draghi et al. 2007; Karlsen et al. 2008; Polkinghorne et al. 2010; Camus et al. 2013; Steigen et al. 2013; Stride et al. 2013a, b). Two Chlamydiales have previously been found to infect and produce epitheliocyst in Atlantic salmon (Salmo salar), 'Candidatus Piscichlamydia salmonis' and 'Candidatus Clavichlamydia ${ }^{1}$ salmonicola' (Draghi et al. 2004; Karlsen et al. 2008). However, a betaproteobacterium, Candidatus Branchiomonas cysticola, has also recently been detected in cysts in the gills of Atlantic salmon (Toenshoff et al. 2012; Mitchell et al. 2013).

Chlamydiae are difficult to culture in vitro and knowledge on the genetic diversity within the phylum mainly

\footnotetext{
${ }^{1}$ First spelled Clavochlamydia by Karlsen et al. (2008), amended to Clavichlamydia in Bergey's manual vol 4 (2010) p 866 (Horn 2011).
} 
relies on 16S rRNA gene sequences. A 16S rRNA gene-based system for classification of Chlamydiales has been recommended that suggests percentage sequence identity limits for the classification into taxa (Everett et al. 1999). Using these thresholds for classification, nine families have been proposed (Horn 2008, 2011; Lagkouvardos et al. 2014). Sequence data that exist from other uncultivable Chlamydiales from fish do, however, suggest an even higher diversity at family level (Horn 2008; Polkinghorne et al. 2010; Corsaro and Work 2012; Camus et al. 2013; Steigen et al. 2013; Stride et al. 2013a, b). The three Chlamydiae associated with epitheliocystis in salmonids, Candidatus Piscichlamydia salmonis, Candidatus Clavichlamydia salmonicola, and Neochlamydia sp. represent three different families (Horn 2008).

During the autumn of 2006, we investigated Atlantic salmon from a farm in Western Norway where the fish showed signs of respiratory distress and had prominent gill lesions. PCR testing and sequencing revealed that a suite of infectious agents were present on the gills of these salmon, including a novel epitheliocystis associated chlamydia with affinities to the family Simkaniaceae. The bacterium was subsequently detected in salmon from other farms in Norway.

Here, we present morphological and genetic data describing the novel chlamydia and demonstrate that its RNA is present in epitheliocysts in infected gills. We suggest a new provisional taxon, 'Candidatus Syngnamydia salmonis' in the family Simkaniaceae, for this new parasitic bacterium infecting Atlantic salmon.

\section{Materials and methods}

\section{Material}

Salmon were collected from three separate seawater farms in Norway (populations PI-PIII) in October 2006 (Table 1). PI was from Northern Norway while PII and PIII were from Western Norway. All fish suffered from gill disease with associated mortality.

Gills were collected from all populations and subsequently processed for histology and nucleic acid extraction.
Gills collected from population PIII were also used for in situ hybridization (ISH).

RNA extraction, reverse transcription RT-PCR and real-time RT-PCR

RNA was extracted from gills and transcribed into cDNA as previously described by Devold et al. (2000). PCR was run with primers 16SIGF, 806R and 16SB1 (Draghi et al. 2004), using cDNA as template for amplification of the nearly complete 16S rRNA gene of the novel chlamydia. Realtime PCR was run as described by Hodneland and Endresen (2006) with primers and probes directed against Candidatus Piscichlamydia salmonis (Nylund et al. 2008) and the novel chlamydia on cDNA template. The real-time assay targeting the new chlamydia consisted of specific primers SCh-F (5'-GGGTAGCCCGATATCTTCAAAGT-3'), SCh-R (5'-CCCATGAGCCGCTCTCTCT-3') and a TaqMan ${ }^{\circledR}$ FAM $^{\text {TM }}$ dyed minor groove binder (MGB) probe (Fam-5'-TCCTTCGGGACCTTAC-3'-MGB).

\section{Sequencing and sequence analysis}

Sequencing of purified PCR products and plasmids was done using an ABI Prism BigDye Terminator Cycle Sequencing Ready Reaction kit, v3.1 (Applied Biosystems, Perkin-Elmer) according to producer's recommendations. Sequencing was done in both directions, and sequences used for phylogenetic studies originated from direct sequencing of PCR products. Sequencing was performed at the sequencing facility at the University of Bergen (http:// www.seqlab.uib.no).

An alignment of 56 16s rRNA gene sequences from the phylum Chlamydiae, retrieved from the GenBank or obtained from the present study, was made using Vector NTI 9.0 software. The alignment included members from all families within order Chlamydiales and several $16 \mathrm{~S}$ rRNA gene sequences obtained from fish gills. Phylogenetic analysis was performed using TREE-PUZZLE 5.2 (available at: http://www.tree-puzzle.de), maximum likelihood (ML). The best-fit nucleotide substitution model for the dataset was GTR $+\mathrm{I}+\mathrm{G}$, identified by Modeltest 3.6 (Posada and Crandall 1998). This model was implemented. Trees were viewed using TreeView (Page 1996).
Table 1 Number of gill samples found positive for two chlamydia in populations I-III, using real-time RT-PCR

Fish from PIII solely infected by the novel Chlamydia were used for in situ hybridization

\begin{tabular}{lllll}
\hline Population & Origin (country) & Mean weight $(\mathrm{g})$ & $\begin{array}{l}\text { Number of positive samples/total number } \\
\text { of samples }\end{array}$ \\
\cline { 4 - 5 } & & 'Cand. P. salmonis' & Novel chlamydia \\
\hline I & Nordland & 264 & $0 / 10$ & $10 / 10$ \\
II & Sogn-og Fjordane & 365 & $25 / 25$ & $25 / 25$ \\
III & Hordaland & 362 & $1 / 10$ & $10 / 10$ \\
\hline
\end{tabular}


Cloning and in vitro transcription of DIG-labelled RNA probes

Digoxigenin-labelled RNA probes against the novel chlamydia, and Candidatus P. salmonis and Candidatus B. cysticola were made as previously described (Karlsen et al. 2008). A DNA fragment (769 bp) coding for the partial 16S rRNA gene sequence from both chlamydia was amplified using primers 16 sSIGF and 806R. A DNA fragment (700 bp) from the 16s DNA gene from Candidatus B. cysticola was amplified using primers. PCR products from Candidatus B. cysticola were used to make the sense/ anti-sense probes (EUGB 27F: 5'-AGAGTTTGATCMTGGCTCAB-3'), (BProto-R1: 5'-GCA TTTCACCGCTACACATGG- $3^{\prime}$ ). The fragment was subsequently cloned into the PCR4-vector (Invitrogen) that carries the T7 promoter. Clones with insert in opposite directions were selected as templates for transcription of RNA in the presence of DIGlabelled dUTP (Roche) to produce DIG-labelled probes in sense and anti-sense orientations. The authenticity of the probes was verified by agarose gel electrophoresis and dot blot analysis using non-labelled RNA transcripts as template.

Histology and transmission electron microscopy (TEM)

Gill tissue samples were fixed by immersion at $6{ }^{\circ} \mathrm{C}$ in a modified Karnovsky's fixative where distilled water had been replaced by Ringer's solution and $4 \%$ (w/v) sucrose solution (Nylund et al. 1995). Before embedding in EMBED-812 (Electron Microscopy Sciences), the tissues were post-fixed in $2 \%(\mathrm{w} / \mathrm{v}) \mathrm{OsO}_{4}$. Semi- and ultra-thin sections were cut on a Reichert-Jung Ultracut E (Leica). Semithin Sects. $(0.5 \mu \mathrm{m})$ for light microscopy were stained with toluidine blue. The ultrathin Sects. $(30-40 \mathrm{~nm})$ were stained for $1.5 \mathrm{~h}$ in $5 \%(\mathrm{w} / \mathrm{v})$ aqueous uranyl acetate solution and then stained with lead citrate.

In situ hybridization (ISH)

ISH were performed on sections of paraffin embedded gills from salmon (PIII) solely infected with the novel chlamydia in order to attach amplified sequences to gill tissue. ISH was performed as described by Xu and Wilkinson (1999) with some adaptations from other protocols: gills were fixed in $4 \%$ paraformaldehyde in $1 \times$ PBS.DEPC. $\mathrm{H}_{2} \mathrm{O}$ at $4{ }^{\circ} \mathrm{C}$ over night, washed twice in $1 \times$ PBS.DEPC. $\mathrm{H}_{2} \mathrm{O}$ at $4{ }^{\circ} \mathrm{C}$ and dehydrated in an ethanol series in PBS.DEPC. $\mathrm{H}_{2} \mathrm{O} ; 25,50$ and $70 \%$. Tissues were kept in $70 \%$ ethanol at $4{ }^{\circ} \mathrm{C}$ for 3 weeks prior to embedding in paraffin wax. Tissues were further dehydrated in a Histokinette (Leica TP 1,020, Leica microsystems); $70 \%$ ethanol, $80 \%$ ethanol, $2 \times 96 \%$ ethanol, $2 \times 100 \%$ ethanol, $2 \times$ Xylene and $2 \times$ molten paraffin wax $\left(60{ }^{\circ} \mathrm{C}\right)$. Paraffin Sects. $(8 \mu \mathrm{m})$ were cut on a Leica RM2255 microtome and floated on a DEPC water bath at $50{ }^{\circ} \mathrm{C}$ until creases disappeared and then collected on polylysine-covered slides. The slides were dried at $40{ }^{\circ} \mathrm{C}$ and then kept at $34{ }^{\circ} \mathrm{C}$ over night. The slides were dewaxed by immersion in Histoclear (National Diagnostics) twice for $10 \mathrm{~min}$. The slides were washed twice in $100 \%$ ethanol for 2 min and rehydrated through an ethanol series in $1 \times$ PBS. DEPC. $\mathrm{H}_{2} \mathrm{O}: 100 \%$ twice, 75,50 and $25 \%$ for $5 \mathrm{~min}$ each. Sections were washed twice in $1 \times$ PBS.DEPC. $\mathrm{H}_{2} \mathrm{O}$, then once in a $0.05 \mathrm{M}$ Tris- $\mathrm{HCl}$ buffer, $\mathrm{pH}$ 7.5. Sections were overlaid with Proteinase K (Promega) for $10 \mathrm{~min}(10 \mu \mathrm{g} /$ $\mathrm{ml}$ ) in a buffer containing $0.05 \mathrm{M}$ TrisHCl and $\mathrm{CaCl}_{2}$ at $\mathrm{pH}$ 9.5. Sections were washed with $0.05 \mathrm{M}$ Tris- $\mathrm{HCl}$ buffer, then $1 \times$ PBS.DEPC. $\mathrm{H}_{2} \mathrm{O}$, refixed for $20 \mathrm{~min}$ in $4 \%$ paraformaldehyde in PBS.DEPC. $\mathrm{H}_{2} \mathrm{O}$ in room temperature, washed three times in $1 \times$ PBS.DEPC. $\mathrm{H}_{2} \mathrm{O}$ for $5 \mathrm{~min}$ and dehydrated 25, 50, 70 and $2 \times 100 \%$ in $1 \times$ PBS.DEPC. $\mathrm{H}_{2} \mathrm{O}$ and dried. Sections were covered with a preheated $\left(65{ }^{\circ} \mathrm{C}\right)$ hybridization mixture containing $50 \%$ formamide, $0.6 \mathrm{mg} / \mathrm{ml}$ yeast tRNA, $2 \%$ blocking reagent $50 \mu \mathrm{g} / \mathrm{ml}$ heparin, $0.1 \%$ Triton-X-100, $5 \times \mathrm{SSC}$, together with denaturized sense and anti-sense probe (heated to $80{ }^{\circ} \mathrm{C}$ for $5 \mathrm{~min}$, $\sim 900 \mathrm{ng} / \mathrm{ml}$ ). Slides were incubated in a moist chamber at $65{ }^{\circ} \mathrm{C}$ over night, with paper soaked in $50 \%$ formamide and $5 \times$ SSC. Slides were washed in $2 \times$ SSC and $25 \%$ formamide for $30 \mathrm{~min}$ at $65^{\circ} \mathrm{C}$, then twice for $30 \mathrm{~min}$ in $2 \times \mathrm{SSC}$, $0.5 \%$ SDS and $0.1 \%$ Sarcosyl, twice for $30 \mathrm{~min}$ in $0.2 \times$ SSC, $0.5 \%$ SDS and $0.1 \%$ Sarcosyl, all at $65{ }^{\circ} \mathrm{C}$. Slides were then washed for $2 \times 15 \mathrm{~min}$ in PBT (PBS with $0.1 \%$ Triton $\mathrm{X}$ ) in room temperature and then covered with $5 \%$ sheep serum in PBT for 30 min. Anti-digoxigenin-alkaline phosphatase were added to PBT $(1: 2,000)$ and incubated at $4{ }^{\circ} \mathrm{C}$ over night $(16 \mathrm{~h})$. Slides were washed two times at room temperature in PBT for $10 \mathrm{~min}$, then three times for $10 \mathrm{~min}$ in PBT, two times in NTMT $(0.1 \mathrm{M}$ Tris $\mathrm{HCl}$ buffer, pH 9.5, $0.1 \%$ Triton-X-100, 0.1 M NaCl, 0.05 $\mathrm{M} \mathrm{MgCl}_{2}$ ) for $5 \mathrm{~min}$. NTMT were added $4.5 \mu \mathrm{l} / \mathrm{ml}$ of NBT and $3.5 \mu \mathrm{l} /$ $\mathrm{ml} \mathrm{BCIP}$ and incubated in dark for $8 \mathrm{~h}$. Slides were then washed in PBT twice and then in DEPC.H2O and overlaid with $70 \%$ glycerol in $0.05 \mathrm{M}$ Tris $\mathrm{HCl}$ buffer, $\mathrm{pH} 9.5$. Sections were observed in a Leitz Aristoplan light microscope, and photographs were taken with an Olympus E-330 camera.

\section{Results}

Sequence analysis

A cDNA fragment was initially amplified by RT-PCR from population P-II using primers specific for 16S rDNA from members in the phylum Chlamydiae. The same sequence 
(100\% identity) was subsequently obtained from salmon in population PI, while the sequence from PIII showed three substitutions (99.8\% similarity). Blast analysis of the PI sequence (Accession no: EU326493; 1342 nt) suggested it belonged to Chlamydiales. The highest nucleotide identity (including indels) was obtained with members of the family Simkaniaceae. Among these, the highest identity (98.1\%) was with an endosymbiont of the marine invertebrate Xenoturbella sp. (EF177461). Another closely related sequence $(97.1 \%)$ was obtained from the gills of a marine fish, the wrasse Symphodus melops from Norway (KC608868). Candidatus Syngnamydia venezia (KC182514) show highest identity $(95.7 \%)$ among the described species that produce epitheliocysts in the gills of fish. Identity with Candidatus Fritschea spp. was 94.3-94.5 \% (AF400484, AY140911), while the 16S rRNA gene sequence of Simkania negevensis (U68460), the type species of the family Simkaniceae, showed $91.7 \%$ identity to the novel chlamydia. Members of the Chlamydiaceae (e.g. D85709, CTU73110) showed an identity between 80 and $85 \%$ to the novel chlamydia from Atlantic salmon (Table 2).

Phylogenetic analyses based on partial 16S rRNA gene sequences from selected members of Chlamydiae place the new bacterium with members of the family Simkaniacea. The novel chlamydia groups with the Xenoturbella sp. symbiont in a sub-clade together with the fish-infecting species Candidatus S. venezia and the unnamed species from S. melops (Fig. 1).

Histology and ultrastructure of epitheliocysts

Histological studies of gills from all populations revealed epitheliocysts. These cysts consisted of single hypertrophied cells with an inclusion containing bacteria (Figs. 2, 3). The largest epitheliocysts had a diameter up to $25 \mu \mathrm{m}$. The large inclusions displaced the cell nucleus (Fig. 3a). Transmission electron microscopy revealed that in addition to bacteria, the inclusions contained small membrane bound particles, and filamentous and amorphous material (Fig. 3). The bacteria in the inclusions showed different morphologies: large elongated, branching bodies (up to $2.5 \mu \mathrm{m}$ in length) containing granular material (ribosomes) and areas with amorphous material (chromatin), here referred to as reticulate body, RB-like (Figs. 2, 3) smaller more electron dense, short rod-like morphs (approximately $0.7-1.0 \times 0.4-0.5 \mu \mathrm{m}$ ) with a distinct apical disc (cap), a sub-apical translucent vacuole-like area (average diameter of $280 \mathrm{~nm}$ ), here referred to as likely elementary bodies (EBs) (Figs. 3, 4), morphs with an intermediate size (500$800 \mathrm{~nm}$ in diameter) compared to the RBs and the EBs also present in the inclusions, here referred to as intermediate bodies (IBs; Fig. 3b, c). All stages of the bacterium were surrounded by two unit membranes, in the sub-apical parts
Table 2 Nucleotide sequence identity of the 16S rRNA gene between the novel fish Simkaniaceae (accession no: EU326493, 1342 nt) and other members in this family

\begin{tabular}{|c|c|c|}
\hline Species & Accession numbers & (\%) Identity \\
\hline \multicolumn{3}{|l|}{ Family Simkaniaceae } \\
\hline Symbiont, Xenoturbella & EF177461 & 98.1 \\
\hline SM081012-5S, S. melops & КС608868 & 97.1 \\
\hline Candidatus Syngnamydia venezia & KC182514 & 95.7 \\
\hline Candidatus Fritschea eriococci & AY140911 & 94.5 \\
\hline Candidatus Fritschea bernisiae & AF400484 & 94.3 \\
\hline Simkania negevensis & SSU68460 & 91.7 \\
\hline \multicolumn{3}{|l|}{ Family Chlamydiaceae } \\
\hline Chlamydia suis & CTU73110 & 84.1 \\
\hline Chlamydophila abortus & D85709 & 83.8 \\
\hline
\end{tabular}

Nucleotide identity is calculated as number of identities divided by total alignment length, including in/dels. SM081012-5S is a $16 \mathrm{~S}$ rRNA gene sequence obtained from the gills of Symphodus melops

of the bacterium, the outer membrane appears irregular and detached from the inner membrane (Fig. 4). In the cap area of mature EBs, the two membranes are aligned at a fixed distance to each other. This area contains rods of electron dense material that appears to traverse both membranes and project from the cap-surface (Fig. 4a, b). In some cases, these rods are also apparent in the cytoplasm of the bacteria, reaching to the vacuole-like body. A prominent nucleoid is located centrally or slightly post-equatorially in the EBs.

\section{In situ RNA-RNA hybridization}

In order to directly relate the amplified sequences to the epitheliocysts in the gills, sense and anti-sense DIG-labelled RNA probes were constructed from the partial 16S rDNA gene of the new Chlamydiae that was amplified from PI. The probes ability to hybridize to positive and negative gill tissues was tested. Gills from S. salar (PIII) suffering from gill diseases and positive by PCR and sequencing for the new chlamydia, reacted with the DIG-labelled anti-sense RNA probe, but not with the corresponding sense probe (Fig. 5). Stained inclusions were observed in clusters unevenly distributed on the gill lamellae but primarily located to the apical half of the secondary lamellae. They appeared always to be covered by a single layer of gill epithelium. Gills from negative $S$. salar were not stained (not shown). As additional negative controls, the homologous part of the 16S RNA gene from 'Candidatus P. salmonis' (nucleotide identity $=78.0 \%$ ) was also cloned and transcribed into sense and anti-sense DIG-labelled RNA probes. None of these probes hybridized to fragments of the infected gills P-III (not shown). The probes (sense/anti-sense) targeting 
Fig. 1 Phylogenetic position of the novel fish Chlamydiae ('Candidatus Syngnamydia salmonis', EU326493). The phylogeny is inferred from sequences of the $16 \mathrm{~S}$ rRNA gene from members of the phylum Chlamydiae, with Candidatus Piscichlamydia salmonis as outgroup. Accession numbers are given in the figure. Family names from the review by Horn (2008; $\mathrm{Ca}$. = Candidatus)

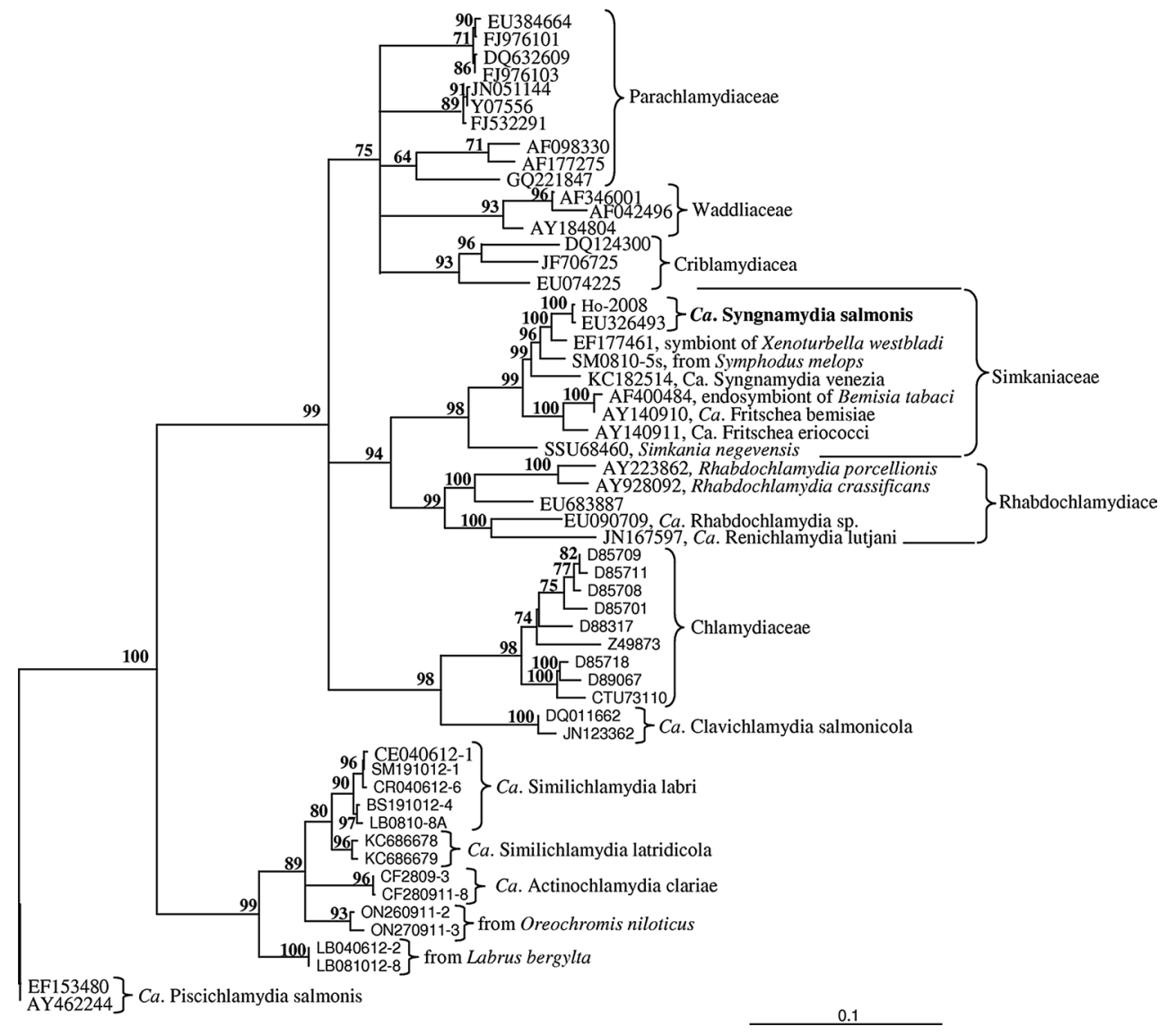

the 16SrRNA from Candidatus B. cysticola were tested in RNA-RNA dot blots using RNA from the new chlamydia and Candidatus B. cysticola. These probes did not hybridize to the $16 \mathrm{~S}$ from the new chlamydia (67\% match).

\section{Discussion}

Gill diseases are causing significant economical losses in the salmonid fish industry in Western Norway. Several pathogens may contribute to the gill pathology observed in S. salar. Most of these pathogens are currently uncultivable and thus unavailable for controlled challenge experiments that could clarify their roles. Three different bacteria cause epitheliocystis in Atlantic salmon. Candidatus Clavichlamydia salmonicola is a freshwater species that disappears 4-6 weeks after sea transfer (Karlsen et al. 2008; Mitchell et al. 2010). Candidatus Piscichlamydia salmonis and Candidatus Branchiomonas cysticola infections are common in seawater-reared salmon, and may be abundant in cases of gill disease (Steinum et al. 2010; Nylund et al. 2011). Candidatus P. salmonis infections may be acquired in freshwater (Steinum et al. 2010), but infections are more severe in salmon developing PGI, suggesting a proliferation of the

Fig. 2 a Hypertrophied epithelial cells containing intracellular, intravacuolar, Chlamydia-like bacteria, in the gills of Atlantic salmon (asterisks). Bar $15 \mu \mathrm{m}$. b Transmission electron microscope pictures of epithelial cells infected with Chlamydia-like bacteria inside inclusions (asterisks) Bar $10 \mu \mathrm{m}$ 


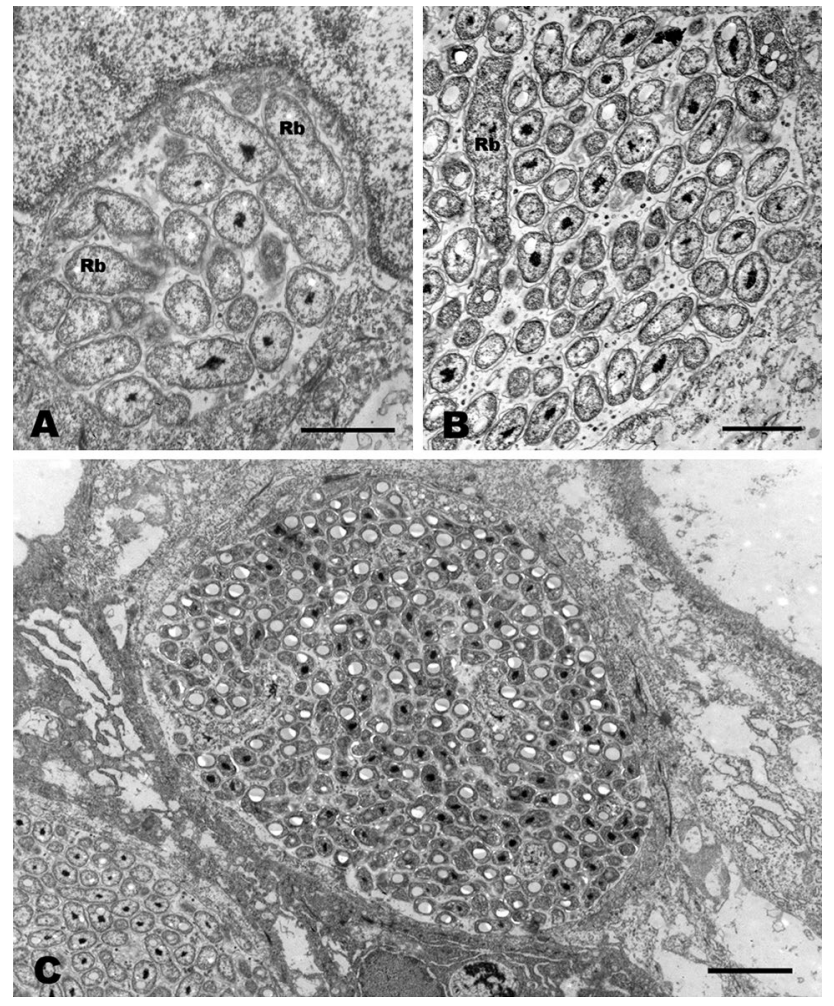

Fig. 3 Early stages in the development of 'Candidatus Syngnamydia salmonis'. a Infected epithelial cell containing a vacuole with reticulate bodies $(R b)$. Host cell nucleus $(N u)$. Bar $1 \mu \mathrm{m}$. b Epithelial cell with an intermediately sized inclusion containing a reticulate body $(R b)$ and smaller intermediate bodies with more condensed nucleoids. Bar $1 \mu \mathrm{m}$. c Infected epithelial cell containing mostly immature elementary bodies with distinct nucleoids and electron-lucent areas. Bar $2 \mu \mathrm{m}$

bacterium also during the seawater phase (Steinum et al. 2010). However, recent studies suggest that Candidatus $P$. salmonis is not a major agent of epitheliocystis in Ireland or Norway (Mitchell et al. 2013). Candidatus B. cysticola infections seem to be acquired in the sea (Mitchell et al. 2013).

The knowledge of the genetic diversity within the phylum Chlamydiae has been greatly expanded the last decade. Sequencing of environmental 16S rRNA gene clones has revealed that Chlamydiae are more diverse than previously assumed (Lagkouvardos et al. 2014). The Simkaniaceae is a relatively recent addition to the Chlamydiae phylum (Everett et al. 1999). The type species, Simkania negevensis, is a widespread human pathogen (Friedman et al. 2003; Kahane et al. 1998, 2002; Lieberman et al. 1997, 2002). Previously known members of Simkaniacea include insect symbionts (Everett et al. 2005), an unnamed symbiont of a marine deuterostome, Xenoturbella westbladi (Israelsson 2007; Kjeldsen et al. 2010), and Candidatus Syngnamydia venezia from gill epitheliocysts in the marine fish Syngnathus typhle (Fehr et al. 2013). Based on 16S gene sequence identity, as well as the phylogenetic analysis, the new Chlamydiales from Atlantic salmon gills is closest related to the chlamydia infecting $X$. westbladi (98.1\% identity), followed by Candidatus S. venezia (95.7\%). According to Stackebrandt and Ebers (2006), a divergence of 1.0-1.3\% in 16S rRNA gene sequences is indicative of separate bacterial species. This threshold range separates it clearly from Candidatus S. venezia as well as from the unnamed Xenoturbella chlamydial symbiont. A sequence (Accession number KC608868) from epitheliocystis infected gills of the marine labrid fish Symphodus melops represents an additional member of the genus (97.1\% identity). Hence, this particular lineage of Simkaniaceae (Candidatus Syngnamydia), infect very different marine host species over a wide geographical area. Indeed, the genetic relationships within the Chlamydiae appear not to correspond well with habitat or geographical location (Horn 2008).

The ISH experiments confirmed that the amplified sequence from the new Chlamydiales was present in inclusions in gill cells of Atlantic salmon. Infected cells occurred in clusters indicating that single-cell infections may have spread to neighbouring cells. The probes targeting Candidatus P. salmonis showed $78.0 \%$ sequence identity to the probes targeting the new Clamydiales and did not react with the gill tissues positive for the latter. The betaproteobacterium Candidatus B. cysticola that also produce epitheliocystis in the gills of salmon (Toenshoff et al. 2012) shows a similarity of only $69.0 \%$ with the probes used in our ISH experiment. The sense and anti-sense probes targeting the new chlamydia did not react with the $16 \mathrm{~S}$ gene from this bacterium, nor did the probes targeting

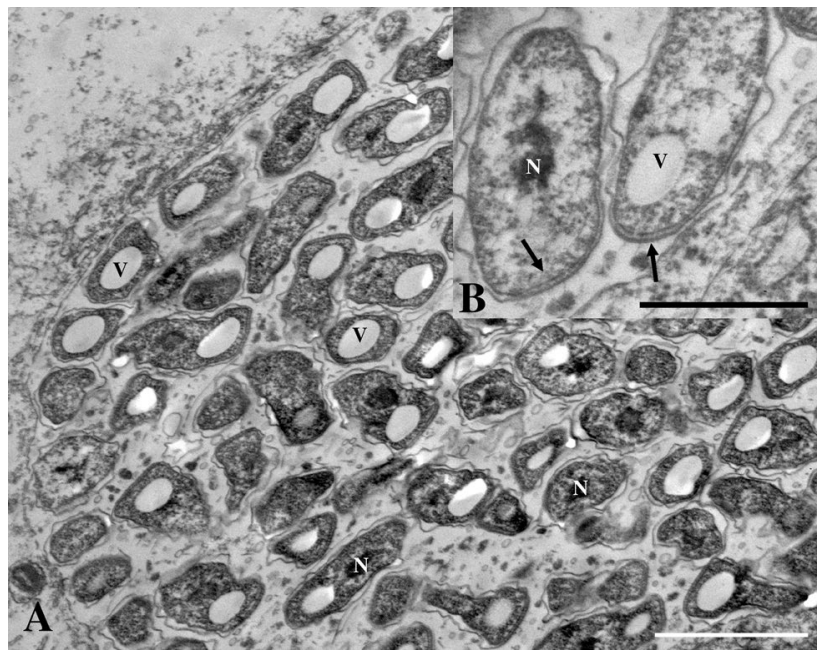

Fig. 4 a Magnification of elementary bodies of 'Candidatus Syngnamydia salmonis'. Nucleoid $(N)$, electron-lucent area $(V)$. Bar $1 \mu \mathrm{m}$. b Magnification of the apical cap (arrows) showing rod-like structures. Bar $0.5 \mu \mathrm{m}$ 

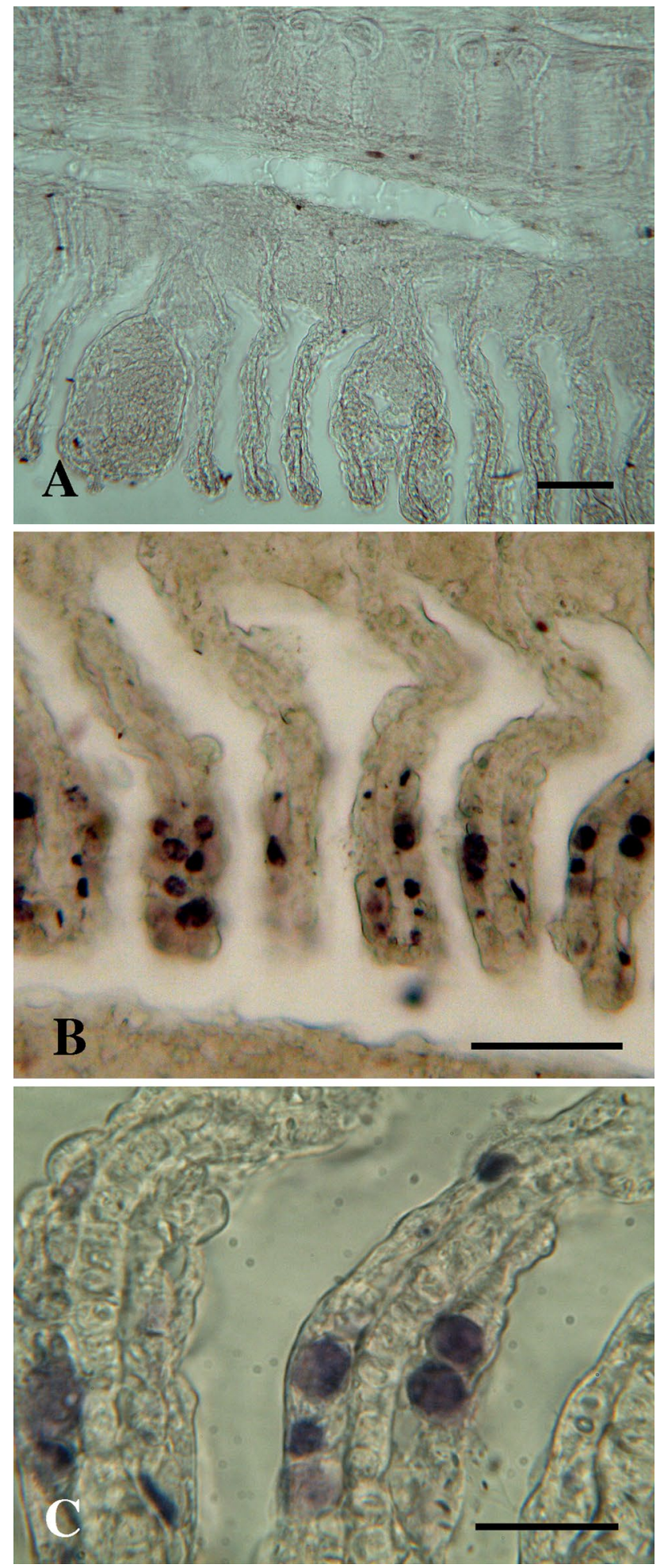

Fig. 5 In situ hybridization on sections of paraffin embedded gills from 'Candidatus Syngnamydia salmonis'-infected fish using DIGlabelled RNA probes. a Gills of infected fish stained with a sense DIG-labelled RNA probe targeting the 16S rRNA from thenovel chlamydia. Bar $100 \mu \mathrm{m}$. b Gills of infected fish stained with an anti-sense DIG-labelled RNA probe. Infected cells are seen as dark dots clustered together in foci. Bar $50 \mu \mathrm{m}$. c Higher magnification of $\mathbf{b} \mathrm{Bar}$ $20 \mu \mathrm{m}$
Candidatus B. cysticola react with the $16 \mathrm{~S}$ gene from the new chlamydia.

The transmission electron microscopy studies of the inclusions of infected cells revealed morphotypes indicating that members of this taxon have a chlamydia-type developmental cycle. Despite that all the studied infections displayed a range of different developmental stages of Chlamydiae, the most structurally advanced stages seen were the presumed EBs, with a rod-armed apical cap and a characteristic large vacuole-like globule. These therefore appear to represent the mature EBs in this species. They differ from the EBs of many other epitheliocyst-forming Chlamydiae in being rod-shaped rather than round. EBs with similar morphology were depicted among the epitheliocystis agents studied by Nylund et al. (1998; e.g. Figs. 6A, 7, 8) from $S$. salar. These may also represent the new chlamydia. Among the closest relatives, an apical cap was observed in the chlamydial symbiont from $X$. westbladi (Israelsson 2007), but not in Candidatus S. venezia. Similar structures also occur in chlamydia-like bacteria from epitheliocysts in other fish hosts (Parperna and Sabnai 1980; Paperna et al. 1981; Crespo et al. 1999; Steigen et al. 2013). A structure similar to the EBs 'vacuole' was not observed in the intracellular chlamydia-like bacterium found in X. westbladi (Israelsson 2007; Kjeldsen et al. 2010) nor in Candidatus S. venezia. No clear EBs were observed by Fehr et al. (2013) in Candidatus S. venezia which may explain the lack of both a cap and perhaps also the 'vacuole'. However, this bacterium did often contain clusters of electron-lucent regions that perhaps could represent related structures to the 'vacuole' found in the present study.

The present report improves our understanding of epitheliocystis and diagnosis of Chlamydiae infections in salmon, and it underscores that the diversity of members of Chlamydiae in fish is higher than previously perceived. It is noteworthy that Chlamydiae infecting fish do not seem to constitute any distinct phylogenetic clade but represent several lineages within this phylum. Three of the four previously known epitheliocystis agents from salmonids are members of the order Chlamydiales with affinities to three different families. Our study adds a fourth family, Simkaniaceae, to the suite of Atlantic salmon gill pathogens.

\section{Description of 'Candidatus Syngnamydia salmonis'}

Candidatus Syngnamydia salmonis; sal.mo.nis, L. n. salmo-onis, salmon; L. gen. n. salmonis. The provisional taxon 'Candidatus Syngnamydia salmonis' contains an intracellular bacterium that infects gill cells of $S$. salar $\mathrm{L}$. (Salmonidae) in the marine environment. Members of this taxon show morphological features indicative of a developmental cycle of replication similar to the Chlamydiae. 
Inclusion membrane simple and smooth. Pleomorphic reticulate bodies (RB) reach $2.5 \mu \mathrm{m}$ in length. RBs develop into IBs $500-800 \mathrm{~nm}$ in length and contain a centrally located electron dense nuclear area c. $150 \mathrm{~nm}$ in diameter. EBs measure 0.7-1.0 $\times 0.4-0.5 \mu \mathrm{m}$. Two unit membranes surround the different developmental stages of the bacterium. EBs have a cap area, a prominent electron-lucent area and an electron dense nucleoid. The cap area is composed of a region where both membranes are aligned with a regular intermembrane space containing electron dense projections. The electron-lucent areas measure $200-350 \mathrm{~nm}$ in diameter.

The 16S rRNA gene of 'Candidatus Syngnamydia salmonis' has been deposited in the GenBank with Accession No. KF768762 (P-I), EU326493 (P-II) and KF768763 (P-III). 'Candidatus Syngnamydia salmonis' is a member of the family Simkaniaceae.

Acknowledgments Eva Andersson at the Institute of Marine Research (IMR), Bergen, Norway, is highly appreciated for sharing her in situ hybridization protocol. Ingrid Uglenes Fiksdal and Anne Torsvik (same affiliation) are also acknowledged for assistance with embedding tissues in paraffin wax.

Open Access This article is distributed under the terms of the Creative Commons Attribution License which permits any use, distribution, and reproduction in any medium, provided the original author(s) and the source are credited.

\section{References}

Camus A, Soto E, Berliner A, Clauss T, Sanchez S (2013) Epitheliocystis hyperinfection in captive spotted eagle rays Aetobatus narinari associated with a novel Chlamydiales 16S rDNA signature sequence. Dis Aquat Org 104:13-21

Corsaro D, Work TM (2012) Candidatus renichlamydia lutjani, a gram-negative bacterium in internal organs of blue-striped snapper Lutjanus kasmira from Hawaii. Dis Aquat Org 98:249-254

Crespo S, Zarza C, Padrós F, Marín de Mateo M (1999) Epitheliocystis agents in sea bream Sparus aurata: morphological evidence for two distinct chlamydia-like developmental cycles. Dis Aquat Org 37:61-72

Devold M, Krossoy B, Aspehaug V, Nylund A (2000) Use of RT-PCR for diagnosis of infectious salmon anaemia virus (ISAV) in carrier sea trout Salmo trutta after experimental infection. Dis Aquat Org 40:9-18

Draghi A II, Popov VL, Kahl MM, Stanton JB, Brown CC, Tsongalis GJ, West AB, Frasca S Jr (2004) Characterization of 'Candidatus Piscichlamydia salmonis' (order Chlamydiales), a chlamydialike bacterium associated with epitheliocystis in farmed Atlantic salmon (Salmo salar). J Clin Microbiol 42:5286-5297

Draghi A II, Bebak J, Popov VL, Noble AC, Geary SJ, West AB, Byrne P, Frasca S Jr (2007) Characterization of a Neochlamydialike bacterium associated with epitheliocystis in cultured Arctic charr Salvelinus alpinus. Dis Aquat Org 76:27-38

Everett KD, Bush RM, Andersen AA (1999) Emended description of the order Chlamydiales, proposal of Parachlamydiaceae fam. nov. and Simkaniaceae fam. nov., each containing one monotypic genus, revised taxonomy of the family Chlamydiaceae, including a new genus and five new species, and standards for the identification of organisms. Int J Syst Bacteriol 49:415-440

Everett KD, Thao M, Horn M, Dyszynski GE, Baumann P (2005) Novel chlamydiae in whiteflies and scale insects: endosymbionts 'Candidatus Fritschea bemisiae' strain falk and 'Candidatus Fritschea eriococci' strain Elm. Int J Syst Evol Microbiol 55:1581-1587

Fehr A, Walther E, Schmidt-Posthaus H, Nufer L, Wilson A, Svercel M, Richter D, Segner H, Pospischil A, Vaughan L (2013) Candidatus Syngnamydia venezia, a novel member of the phylum chlamydiae from broad noosed pipefish. Sygnathus typhle. PLoS ONE 8(8):e70853. doi:10.1371/journal.phone.0070853

Friedman MG, Dvoskin B, Kahane S (2003) Infections with the chlamydia-like microorganism Simkania negevensis, a possible emerging pathogen. Microbes Infect 5:1013-1021

Hodneland K, Endresen C (2006) Sensitive and specific detection of Salmonid alphavirus using real-time PCR (TaqMan (R)). J Virol Methods 131:184-192

Hoffman GL, Dunbar CE, Wolf K, Zwillenberg LO (1969) Epitheliocystis, a new infectious disease of the bluegill (Lepomis macrochirus). Antonie Van Leeuwenhoek 35:146-158

Horn M (2008) Chlamydiae as symbionts in eukaryotes. Annu Rev Microbiol 62:113-131

Horn M (2011) Phylum XXIV. Chlamydiae Garrity and Holt 2001. In: Bergey's manual of systematic bacteriology. 2nd ed. vol 4 . Springer

Israelsson O (2007) Chlamydial symbionts in the enigmatic Xenoturbella (Deuterostomia). J Invertebr Pathol 96:213-220

Kahane S, Greenberg D, Friedman MG, Haikin H, Dagan R (1998) High prevalence of "Simkania Z," a novel chlamydia-like bacterium, in infants with acute bronchiolitis. J Infect Dis 177:1425-1429

Kahane S, Kimmel N, Friedman MG (2002) The growth cycle of Simkania negevensis. Microbiology 148:735-742

Karlsen M, Nylund A, Watanabe K, Helvik JV, Nylund S, Plarre H (2008) Characterization of 'Candidatus Clavochlamydia salmonicola': an intracellular bacterium infecting salmonid fish. Environ Microbiol 10:208-218

Kjeldsen KU, Obst M, Nakano H, Funch P, Schramm A (2010) Two types of endosymbiotic bacteria in the enigmatic marine worm Xenoturbella bocki. Appl Environ Microbiol 76:2657-2662

Lagkouvardos I, Weinmaier T, Lauro FM, Cavicchioli R, Rattei T, Horn M (2014) Integrating metagenomic and amplicon databases to resolve the phylogenetic and ecological diversity of the Chlamydiae. ISME J 8:115-125

Lieberman D, Kahane S, Lieberman D, Friedman MG (1997) Pneumonia with serological evidence of acute infection with the chlamydia-like microorganism "Z". Am J Respir Crit Care Med 156:578-582

Lieberman D, Dvoskin B, Lieberman D, Kahane S, Friedman MG (2002) Serological evidence of acute infection with the chlamydia-like microorganism Simkania negevensis $(\mathrm{Z})$ in acute exacerbation of chronic obstructive pulmonary disease. Eur $\mathbf{J}$ Clin Microbiol Infect Dis 21:307-309

Meijer A, Roholl PJ, Ossewaarde JM, Jones B, Nowak BF (2006) Molecular evidence for association of Chlamydiales bacteria with epitheliocystis in leafy seadragon (Phycodurus eques), silver perch (Bidyanus bidyanus), and barramundi (Lates calcarifer). Appl Environ Microbiol 72:284-290

Mitchell SO, Steinum T, Rodger H, Holland C, Falk K, Colquhoun DJ (2010) Eptheliocystis in Atlantic salmon, Salmo salar L., farmed in fresh water in Ireland is associated with 'Candidatus Clavochlamydia salmonicola' infection. J Fish Dis 33:665-673

Mitchell SO, Steinum TM, Toenshoff ER, Kvellestad A, Falk K, Horn M, Colquhoun DJ (2013) Candidatus Branchiomonas cysticola is a common agent of epitheliocystis in seawater-farmed Atlantic salmon in Norway and Ireland. Dis Aquat Org 103:35-43 
Nylund A, Hovland T, Watanabe K, Endresen C (1995) Presence of infectious salmon anemia virus (ISAV) in tissues of Atlantic salmon, Salmosalar L, collected during three separate outbreaks of the disease. J Fish Dis 18:135-145

Nylund A, Kvenseth AM, Isdal E (1998) A morphological study of the epitheliocystis agent in farmed Atlantic salmon. J Aquat Anim Health 10:43-55

Nylund A, Watanabe K, Nylund S, Karlsen M, Sæther PA, Arnesen CE, Karlsbakk E (2008) Morphogenesis of salmonid gill poxvirus associated with proliferative gill disease in farmed Atlantic salmon (Salmo salar) in Norway. Arch Virol 153:1299-1309

Nylund S, Andersen L, Sævareid I, Plarre H, Watanabe K, Arnesen CE, Karlsbakk E, Nylund A (2011) Diseases of farmed Atlantic salmon (Salmo salar) associated with the microsporidian Paranucleospora theridion. Dis Aquat Org 94:41-57

Page RD (1996) Treeview: an application to display phylogenetic trees on personal computers. Comput Appl Biosci 12:357-358

Paperna I, Sabnai I, Zachary A (1981) Ultrastructural studies in piscine epitheliocystis: evidence for a pleomorphic developmental cycle. J Fish Dis 4:459-472

Parperna I, Sabnai I (1980) Epitheliocystis disease in fish. In: Ahne W (ed) Fish diseases. Third COPRAQ session. Springer, Berlin, pp 228-234

Polkinghorne A, Schmidt-Posthaus H, Meijer A, Lehner A, Vaughan L (2010) Novel Chlamydial associated with epitheliocystis in a leopard shark Triakis semifasciata. Dis Aquat Org 91:75-81

Posada D, Crandall KA (1998) MODELTEST: testing the model of DNA substitution. Bioinformatics 14:817-818

Stackebrandt E, Ebers J (2006) Taxonomic parameters revisited: tarnished gold standards. Microbiol Today 33:152-155
Steigen A, Nylund A, Akoll P, Fiksdal IU, Karlsbakk E, Nylund S, Odong R, Plarre H, Semyalo R, Skår C, Watanabe K (2013) 'Cand. Actinochlamydia clariae' gen. nov., sp. nov., a unique intracellular bacterium causing epitheliocystis in catfish (Clarias gariepinus) in Uganda. PLoS ONE 8(6):e66840. doi:10.1371/ journal.pone.0066840

Steinum T, Kvellestad A, Colquhoun DJ, Heum M, Mohammad S, Grøntvedt RN, Falk K (2010) Microbial and pathological findings in farmed Atlantic salmon Salmo salar with proliferative gill inflammation. Dis Aquat Org 91:201-211

Stride MC, Polkinghorne A, Miller TL, Groff JM, LaPatra SE, Nowak BF (2013a) Molecular characterization of "Candidatus Parilichlamydia carangidicola", a novel chlamydia-like epitheliocystis agent in yellowtail kingfish, Seriola lalandi (Valenciennes), and the proposal of a new family, "Candidatus Parilichlamydiaceae" fam.nov. (Order Chlamydiales). Appl Environ Microbiol 79(5):1590-1597

Stride MC, Polkinghorne A, Miller TL, Nowak BF (2013b) Molecular characterisation of "Candidatus Similichlamydia latridicola gen. nov., sp. nov'. (Chlamydiales: parilichlamydiaceae), a novel chlamydia-like epitheliocystis agent in striped trumpeter, Latris lineata (Forster). Appl Environ Microbiol 79(16):4914-4920. doi:10.1128/AEM.00746-13

Toenshoff ER, Kvellestad A, Mitchell SO, Steinum T, Falk K, Colquhoun DJ, Horn M (2012) A novel betaproteobacterial agent of gill epitheliocystis in seawater farmed Atlantic salmon (Salmo salar). PLoS ONE 7(3):e32696. doi:10.1371/journal. pone.0032696

Xu Q, and Wilkinson DG (1999) In situ hybridization. A practical approach., 2 nd ed. Oxford University Press, New York 